\title{
UJI EFEKTIVITAS EKSTRAK RIMPANG RUMPUT TEKI (Cyperus rotundus L.) DENGAN OBAT IMODIUM TERHADAP ANTIDIARE PADA MENCIT (Mus musculus L.) JANTAN YANG DIINDUKSI OLEUM RICINI
}

\section{TESTING THE EFEKTIVINESS OF NUT-GRASS RHIZOME EXTRACT (Cyperus rotundus) AND IMODIUM TOWARDS ANTIDIARRHEA OF A MALE HOUSE MOUSE (Mus musculus L.) INDUCED WITH OLEUM RICINI}

\author{
Afrisa Herni Putri ${ }^{1^{*}}$, Hendri Busman ${ }^{1}$, dan Nuning Nurcahyani ${ }^{1}$ \\ Jurusan Biologi Fakultas Matematika dan IImu Pengetahuan Alam Universitas Lampung \\ ”afrisaputri15@gmail.com
}

\begin{abstract}
Abstrak
Diare merupakan pengeluaran feses cair berulang kali atau lebih dari tiga kali sehari. Penyebab diare bermacam-macam, antara lain adanya infeksi virus, infeksi bakteri, makanan basi, beracun atau alergi terhadap makanan. Zat aktif kimia yang terdapat dalam rimpang rumput teki $(C$. rotundus L.) teki antara lain: alkaloid, flavonoid, tanin, pati, glikosida serta secara farmakologi rimpang teki mengandung senyawa antidiare sedangkan obat imodium merupakan obat kimia yang dapat mengatasi penyakit diare. Dengan adanya berbagai zat kimia tersebut maka dilakukan penelitian mengenai uji efektivitas ekstrak rimpang rumput teki ( $C$. rotundus L.) dengan obat imodium untuk mencegah terjadinya diare. Penelitian ini dilaksanakan di Laboratorium Zoologi Jurusan Biologi FMIPA Universitas Lampung pada bulan April-Juni 2016. Tujuan penelitian ini adalah untuk membandingkan efektivitas ekstrak rimpang rumput teki dengan obat imodium dalam upaya menurunkan diare. Penelitian ini menggunakan Rancangan Acak Lengkap (RAL) dengan 5 perlakuan, kontrol negatif, diberi $0,4 \mathrm{ml} / 40 \mathrm{gr}$ BB aquabides (A), dosis ekstrak rumput teki $4,5 \mathrm{mg} /$ $40 \mathrm{gr} \mathrm{BB}$ dalam $0,4 \mathrm{ml} / 100 \mathrm{grBB}$ aquabides (B), dosis ekstrak rumput teki $45 \mathrm{mg} / 40 \mathrm{grBB}$ dalam $0,4 \mathrm{ml} / 100 \mathrm{gr} \mathrm{BB}$ aquabides (C), dosis ekstrak rumput teki $135 \mathrm{mg} / 40 \mathrm{grBB}$ dalam 0,4ml/100 gr BB aquabides (D), dosis obat antidiare dengan dosis $0,4 \mathrm{mg}$ dalam $0,4 \mathrm{ml} / 100 \mathrm{gr}$ BB aquabides (E). Kesimpulan penelitian ini adalah ekstrak rimpang rumput teki (C. rotundus L.) dengan dosis 135 $\mathrm{mg} / 40 \mathrm{grBB}$ dapat menunjukkan adanya khasiat antidiare, tetapi efeknya lebih kecil dibandingkan dengan obat imodium (Loperamide). Hal ini disebabkan karena di dalam rimpang rumput teki terkandung senyawa flavonoid dan alkaloid sebagai senyawa antidiare pada mencit.
\end{abstract}

Kata Kunci : diare, mencit (Mus musculus L.), rimpang rumput teki, flavonoid obat imodium

\begin{abstract}
Diarrhea is an illness where the bowel movement happens frequently or more than three times a day. There are many causes of diarrhea, including virus infection, bacterial infection, spoiled or toxic food, or allergic to foods. The active chemical substances contained in the java grass or nutgrass rhizomes (C. rotundus L.) include: alkaloids, flavonoids, tannins, starch, glycosides and pharmacologically, such nut-grass rhizome contains an antidiarrheal compound, while Imodium is a chemical drug that can cure diarrhea. With the wide range of such chemicals substances, a research was conducted to test the effectiveness between nut-grass rhizome extract ( $C$. rotundus L.) with imodium medication to cure diarrhea. This study was conducted at the Laboratory of Zoology Department of Biology, the University of Lampung during April-June 2016. This study aims to compare the effectiveness of nut-grass rhizome extract with Imodium medication in curing diarrhea. This study used a completely randomized design (CRD) with 5 treatments, negative control, were given $0.4 \mathrm{ml} / 40 \mathrm{gr}$ BB aquabidest (A), nut-grass extract dose $4.5 \mathrm{mg} / 40 \mathrm{gr}$ BB in $0,4 \mathrm{ml} / 100 \mathrm{grBB}$ aquabidest (B), the dose of nut-grass extract $45 \mathrm{mg} / 40 \mathrm{grBB}$ in $0,4 \mathrm{ml} / 100 \mathrm{gr}$ aquabidest BB (C), nut-grass extract dose $135 \mathrm{mg} / 40 \mathrm{grBB}$ in $0,4 \mathrm{ml} / 100 \mathrm{gr}$ BB aquabidest (D), the dose of antidiarrheal drug $0.4 \mathrm{mg}$ in $0.4 \mathrm{ml} / 100 \mathrm{~g}$ aquabidest $\mathrm{BB}(\mathrm{E})$. Conclusion of this study is the nut-grass rhizome extract (C. rotundus L.) at a dose of $135 \mathrm{mg} / 40 \mathrm{grBB}$ indicated the efficacy of antidiarrheal, with small effect compared to Imodium (Loperamide). It happened because the nut-grass rhizome contains flavonoids and alkaloids as antidiarrheal compound in curing diarrhea of the house mouse.
\end{abstract}

Keywords: diarrhea, house mouse (Mus musculus L.), nut-grass rhizome, flavonoid, imodium 


\section{PENDAHULUAN}

Diare merupakan penyakit yang sering terjadi dan tersebar luas di seluruh penjuru dunia. Diare dapat menyebabkan lebih dari 4 juta kematian setiap tahunnya pada anak-anak balita. Khususnya di negara berkembang, diare menjadi penyebab utama malnutrisi kalori protein dan dehidrasi (Harrison, 1999).

Upaya penanggulangan diare dapat dilakukan dengan obat modern dan obat tradisional yang penggunaannya sudah banyak dilakukan secara turun-temurun. Penggunaan tumbuhan sebagai obat tradisional banyak diminati sehubungan dengan adanya efek samping dari penggunaan obat modern. Obat tradisional lebih dipilih karena dianggap mempunyai efek samping yang lebih kecil. Perlu diperhatikan pernyataan sementara para pakar kesehatan, obat tradisional maupun obat modern tetap mempunyai efek samping tetapi jika keduanya dibandingkan maka efek samping obat tradisional masih lebih kecil daripada efek samping obat modern (Duryatmo, 2003).

Rumput teki merupakan tumbuhan serbaguna, banyak digunakan dalam pengobatan tradisional di seluruh dunia untuk mengobati kejang perut, luka, bisul dan lecet. Sejumlah aktivitas farmakologi dan biologi termasuk anti-candida, antiinflamasi, antidiabetes, antidiare, sitoprotektif, antimutagenik, antibakteri, antioksidan, sitotoksik dan apoptosis, aktivitas analgesik dan antipiretik telah dilaporkan untuk tumbuhan ini (Lawal dan Adebola, 2009).
Loperamide $\mathrm{HCl}$ merupakan obat antidiare yang bekerja dengan cara bereaksi langsung pada otot-otot usus, menghambat peristaltis dan memperpanjang waktu transit, mempengaruhi perpindahan air dan elektrolit melalui mukosa usus, mengurangi volume fecal, menaikkan viskositas dan mencegah kehilangan air dan elektrolit (Tjay dan Rahardja, 2007).

Menurut Arif (1995) oleum ricini atau castor coil atau minyak jarak berasal dari biji Ricinus communis suatu trigleserida risenosolat dan asam lemak tidak jenuh. Di dalam usus halus minyak jarak dihidrolisis oleh enzim lipase menjadi gliserol dan asam risenosolat. Asam risenosolat inilah yang merupakan bahan aktif sebagai pencahar. Minyak jarak menyebabkan dehidrasi yang disertai gangguan elektrolit. Obat ini merupakan bahan induksi diare pada penelitian diare secara ekperimental pada hewan percobaan.

\section{BAHAN DAN METODE}

\section{Bahan}

Penelitian ini telah dilaksanakan di Laboratorium Zoologi, Jurusan Biologi, Fakultas Matematika dan IImu Pengetahuan Alam, Universitas Lampung dari bulan April sampai Juni 2016. Alat yang digunakan dalam penelitian ini antara lain: kandang mencit yang terbuat dari kawat dan bak plastik sebanyak 25 kandang, tempat makanan dan minuman mencit, kertas label, spuit merupakan, sondelambung, erlenmeyer, sonde lambung, pipet tetes , tabung reaksi dan stopwatch. 
Bahan-bahan yang digunakan dalam penelitian ini adalah 25 ekor mencit jantan yang berumur 2-3 bulan dengan berat badan 35- $40 \mathrm{gr}$, ekstrak rimpang rumput teki (Cyperus rotundus L.), obat imodium, pelet ayam, aquabides, alkohol $70 \%$ dan oleum ricini.

\section{Metode}

Pembuatan Ekstrak Rumput Teki (Cyperus rotundus $\mathrm{L}$ )

Rumput teki yang digunakan sebagai bahan utama dalam pembuatan ekstrak diambil dari Universitas Lampung. Rumput teki yang didapat diidentifikasi terlebih dahulu sebelum dibuat ekstrak untuk memastikan bahwa rimpang yang diambil berasal dari tumbuhan rumput teki (Cyperus rotundus L.), kemudian rimpang yang diperoleh dari rumput teki yang sudah diidentifikasi dibersihkan dan dijemur sampai kering. Akar serabut yang ada pada rumput teki dipotong sehingga hanya tertinggal rimpangnya, kemudian dijemur. Setelah rimpang tersebut kering, dilanjutkan dengan menggiling rimpang hingga menjadi serbuk, kemudian serbuk tersebut dimasukkan kedalam soxhlet dan ditambahkan pelarut metanol. Setelah itu ekstrak dipekatkan dengan rotary evaporator dengan suhu $35^{\circ} \mathrm{C}$ dan kecepatan $60 \mathrm{rpm}$ selama 1 jam sehingga menghasilkan ekstrak rimpang rumput teki yang pekat.

\section{Pemberian Perlakuan Hewan Uji} Induksi Oleum Ricini

Masing-masing mencit ditimbang terlebih dahulu untuk mengetahui berat badan yang berhubungan dengan banyaknya pemberian dosis oleum ricini yang diinduksikan. Dengan menggunakan dosis $150 \mathrm{mg} / \mathrm{kg}$ berat badan.
Proses penyimpanan sampai proses penyuntikan oleum ricini dilakukan pada suhu dingin supaya oleum ricini tidak rusak. Oleum ricini yang telah ditimbang (sesuai konversi dengan berat badan masing-masing mencit) kemudian dilarutkan dengan $0,9 \% \mathrm{NaCl}$ untuk masing-masing pada mencit

\section{b. Diare Pada Mencit}

Mencit diinduksi oleum ricini pada hari ke-8, mencit dikelompokkan menjadi 5 kelompok yaitu 1, 2, 3, 4,dan 5 yang setiap kelompok terdiri dari 5 ekor mencit. Setiap mencit diberi oleum ricini sebanyak $0,15 \mathrm{mg} / \mathrm{g}$ BB menggunakan $\mathrm{NaCl}$ sebagai pelarut sebanyak $0,9 \%$ dan syringe $1 \mathrm{ml}$ secara ip (intraperitoneal) pada bagian rongga perut. Penginduksian oleum ricini dilakukan dengan cara steril, pada bagian intraperitoneal dibersihkan dengan cara diusap menggunakan kapas yang telah diberi alkohol $70 \%$. Kemudian larutan oleum ricini yang terdapat pada syringe dapat diinjeksikan pada mencit.

\section{Pemberian Ekstrak Rimpang Rumput Teki}

Pemberian obat dan ekstrak rimpang rumput teki terhadap mencit dengan cara dicekok menggunakan alat berupa sonde lambung. Terdapat lima kelompok perlakuan, sebagai berikut:

1. Kelompok $A$ : kontrol negatif, diberi $0,4 \mathrm{ml}$ 140 gr BB aquabides

2. Kelompok B: dosis ekstrak rumput teki 4,5 $\mathrm{mg} / 40 \mathrm{gr}$ BB dalam $0,4 \mathrm{ml} / 100 \mathrm{grBB}$ aquabides

3. Kelompok C: dosis ekstrak rumput teki 45 $\mathrm{mg} / 40$ grBBdalam $0,4 \mathrm{ml} / 100 \mathrm{gr}$ BB aquabides 
4. Kelompok $D$ : dosis ekstrak rumput teki $135 \mathrm{mg} / 40 \mathrm{grBB}$ dalam $0,4 \mathrm{ml} / 100 \mathrm{gr}$ BB aquabides

5. Kelompok E: kontrol positif, obat antidiare dengan dosis $0,4 \mathrm{mg}$ dalam $0,4 \mathrm{ml} / 100 \mathrm{gr}$ BB aquabides

\section{Pemeriksaan Diare}

Mencit diberikan bahan percobaan yakni ekstrak rimpang rumput teki dan obat imodium loperamide kemudian mencit dibuat agar diare menggunakan oleum ricini sebanyak $150 \mathrm{mg} / \mathrm{kg}$ berat badan. Oleum ricini berfungsi untuk membuat mencit agar diare. Pemeriksaan antidiare ini dilakukan 10 kali selama 5 jam, meliputi waktu terjadinya diare, frekuensi diare, dan konsistensi feses (padat, setengah padat, dan cair). Mencit dipuasakan terlebih dahulu sebelum dilakukan pengamatan diare, pada saat mencit dipuasakan, sekam yang ada di kandang dikeluarkan agar tidak dimakan oleh mencit.

\section{Analisis Data}

Parameter yang diamati dalam penelitian ini adalah waktu terjadinya diare, frekuensi diare, dan konsistensi feses (padat,setengah padat, dan cair) pada mencit (Mus musculus L.) jantan. Data yang telah diperoleh dianalisis menggunakan Analisis of Variance (ANOVA). Apabila ada perbedaan nyata akan dilanjutkan menggunakan uji BNT (beda nyata terkecil) pada taraf $5 \%$ sebagai perbandingan dari masing-masing perlakuan.

\section{HASIL DAN PEMBAHASAN}

Data Rata-rata Waktu terjadinya Daire Setelah Pemberian Ekstrak Rimpang

\section{Rumput Teki (Cyperus rotundus L.) dan Obat Imodium}

Setelah dilakukan ANOVA menunjukkan hasil waktu terjadinya diare pada hewan uji baik kelompok $A, B, C, D$ dan $E$ setelah dihitung secara statistika menggunakan ANOVA menunjukkan terdapat perbedaan nyata. Hal ini berarti waktu terjadinya diare setelah induksi dengan oleum ricini semua kelompok dapat memperpanjang waktu diare tetapi masih lebih kecil dibandingkan dengan obat imodium loperamide.

Tabel 1. Rata-rata waktu terjadinya diare mencit jantan setelah pemberian ekstrak rimpang rumput teki dan obat Imodium

\begin{tabular}{cc}
\hline Perlakuan & $\begin{array}{c}\text { Waktu terjadinya diare (menit) } \\
\text { X } \pm \text { SD }\end{array}$ \\
\hline A & $102 \pm 16,432^{\mathrm{a}}$ \\
B & $138 \pm 16,432^{\mathrm{ab}}$ \\
C & $144 \pm 95,812^{\mathrm{ab}}$ \\
D & $264 \pm 65,038^{\mathrm{c}}$ \\
E & $288 \pm 16,432^{\mathrm{c}}$ \\
\hline Keterangan: Angka yang diikuti huruf \\
\multicolumn{2}{c}{ superskrip berbeda } \\
menunjukkan beda nyata \\
berdasarkan uji BNT 5\%.
\end{tabular}

Hasil analisis statistik menggunakan ANOVA dengan taraf signifikasi 5\% menunjukkan hasil yang signifikan. Kemudian dilakukan uji lanjut menggunakan BNT dengan taraf 5\% terhadap hasil tersebut menunjukkan adanya perbedaan nyata antara kontrol dengan perlakuan dosis $135 \mathrm{mg} / 40$ gram BB (D) dan ada perbedaan yang nyata antara kontrol aquades (A) dengan obat imodium loperamide dosis $0,4 \mathrm{mg} / 40 \mathrm{gramBB}$. Namun tidak terdapat perbedaan yang nyata antara kontrol dengan perlakuan dosis 4,5mg/40gramBB (B) dan dosis $45 \mathrm{mg} / 40 \mathrm{gram}$ BB (C). Dari urian di atas dapat dikatakan bahwa ektrak rumput teki 
dengan dosis $135 \mathrm{mg} / \mathrm{gram}$ BB (D) dapat memperpanjang waktu terjadinya diare tetapi masih lebih kecil dibandingkan dengan obat imodium loperamide. Hal ini dapat dilihat pada Gambar 1.

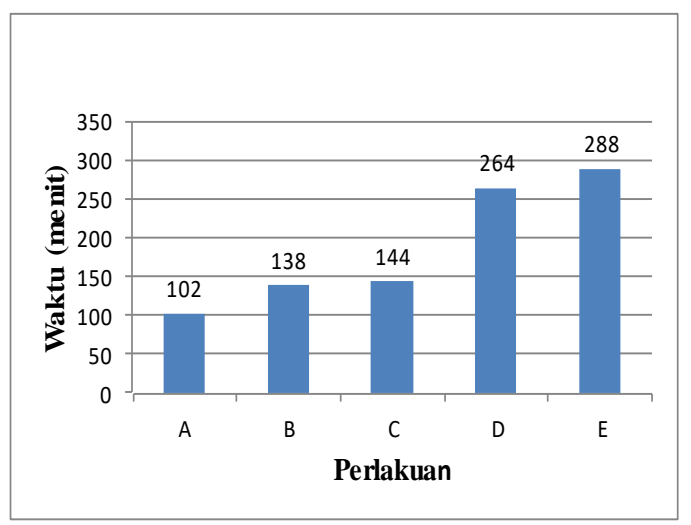

Gambar 1. Grafik waktu tejadinya diare setelah pemberian ekstrak rimpang rumput teki dan obat imodium (Keterangan: A: Kontrol(Aquades), B: Ektrak teki 4,5mg/40gram BB, C: Ektrak teki $45 \mathrm{mg} / 40 \mathrm{gram}$ BB, D: Ektrak teki $135 \mathrm{mg} / 40 \mathrm{gram}$ BB, E: Imodium 0,4mg/40gramBB)

Berdasarkan Gambar 3, rata-rata waktu terjadinya setelah diberi perlakuan kontrol aquades (A) dengan dosis 135 $\mathrm{mg} / 40 \mathrm{gramBB}$ (D) dan dosis obat imodium 0,4mg/ 40gram BB mengalami kenaikan waktu terajdinya diare. Hal ini berarti waktu terjadinya diare setelah diberi perlakuan ekstra rimpang teki dosis $135 \mathrm{mg} / 40 \mathrm{gramBB}$ dan dosis obat Imodium 0,4mg/ 40gram BB dapat memperpanjang waktu terjadinya diare. Pemberian obat 1 jam sebelum perangsang diare bertujuan untuk memberi kesempatan obat tersebut melakukan proses absorbsi terlebih dahulu sehingga begitu oleum ricini diberikan obat langsung bekerja tidak butuh waktu yang lama untuk berefek antidiare.

2.Data Rata-rata Frekuensi terjadinya Diare Setelah Pemberian Ekstrak Rimpang
Rumput Teki (Cyperus rotundus L.) dan Obat Imodium

Setelah dilakukan Analisis of Variance (ANOVA) menunjukkan hasil pemberian ekstrak rimpang rumput teki dan obat Imodium dapat menurunkan frekuensi terjadinya diare, sehingga dapat dilanjutkan dengan uji BNT pada taraf $5 \%$, hasilnya seperti dapat dilihat pada Tabel 2.

Tabel 2. Rata-rata frekuensi diare mencit jantan setelah pemberian ekstrak rimpang rumput teki dan obat Imodium

\begin{tabular}{cl}
\hline Perlakuan & \multicolumn{1}{c}{$\begin{array}{c}\text { Frekuensi diare } \\
(\mathrm{X} \pm \mathrm{SD})\end{array}$} \\
\hline A & $5,8 \pm 0,837 \mathrm{a}$ \\
B & $4,6 \pm 1,342 \mathrm{~b}$ \\
C & $3,2 \pm 0,837 \mathrm{~b}$ \\
D & $2,4 \pm 0,548 \mathrm{bc}$ \\
E & $3 \pm 0,707 \mathrm{~b}$
\end{tabular}

Keterangan: Angka yang diikuti huruf superskrip berbeda menunjukkan beda nyata berdasarkan uji BNT 5\%.

Berdasarkan Tabel 2, rata-rata frekuensi diare pada mencit jantan setelah dilakukan analisis varian dengan taraf signifikasi $5 \%$, menunjukkan hasil yang signifikan. Kemudian dilakukan uji lanjut menggunakan BNT dengan taraf $5 \%$ terhadap hasil tersebut menunjukkan adanya perbedaan nyata antara kontrol aquades $(A)$ dengan perlakuan dosis $4,5 \mathrm{mg} / 40$ gram BB (B), 45mg/40gram $\mathrm{BB}(\mathrm{C}), 135 \mathrm{mg} / 40$ gram $\mathrm{BB}(\mathrm{D})$, dan ada perbedaan nyata antara obat imodium 0,4mg/40gram BB dengan ekstra rimpang rumput teki dosis $135 \mathrm{mg} / 40 \mathrm{gram}$ BB. Dari ketiga dosis yang diberikan yaitu ektrak rimpang teki dengan dosis $4,5 \mathrm{mg} / 40$ gram BB (B),45MG/40gram BB(C), 90mg/40BB, 
$135 \mathrm{mg} / 40$ gram BB(D) bahwa semakin besar dosis yang diberikan maka akan semakin kecil frekuensi terjadinya diare. Hal ini dapat dilihat pada Gambar 5.

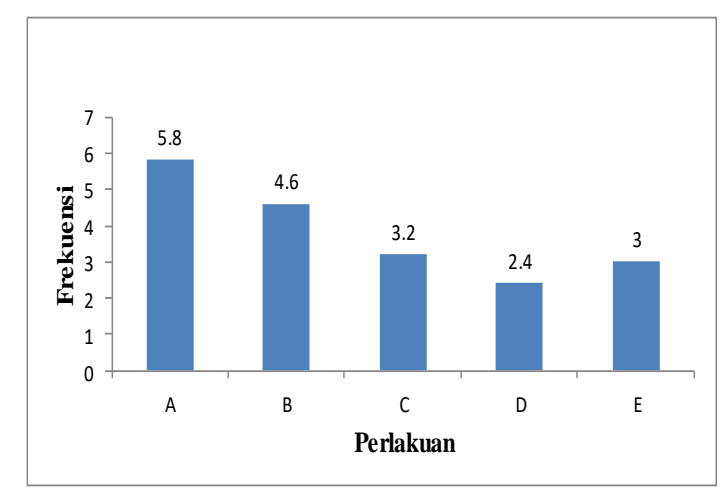

Gambar 2. Grafik penurunan frekuensi setelah pemberian ekstrak rimpang rumput teki dan obat Imodium ((Keterangan: A: Kontrol(Aquades), B: Ektrak teki 4,5mg/40gram BB, C: Ektrak teki $45 \mathrm{mg} / 40 \mathrm{gram}$ BB, D: Ektrak teki $135 \mathrm{mg} / 40 \mathrm{gram}$ $\mathrm{BB}, \quad \mathrm{E}: \quad$ Imodium $0,4 \mathrm{mg} / 40$ gramBB)

Berdasarkan Gambar 5, rata-rata frekuensi diare mencit setelah diberi perlakuan dosis $45 \mathrm{mg} / 40$ gram BB (B), dosis $90 \mathrm{mg} / 40$ gram BB (C), dan dosis $135 \mathrm{mg} / 40$ gram BB (D) mengalami penurunan frekuensi diare dan ada penurnan antara obat imodium 0,4mg/40gram BB dengan ekstrak rimpang rumput teki dosis $135 \mathrm{mg} / 40 \mathrm{gram}$ BB. Dari ketiga dosis ektrak rimpang rumput teki menunjukkan bahwa semakin besar dosis ektrak rimpang rumput teki yang diberikan maka akan semakin kecil frekuensi terjadinya diare.

Setelah dilakukan Analisis of Variance (ANOVA) menunjukkan hasil pemberian ekstrak rimpang rumput teki dan obat Imodium dapat memperbaiki konsistensi feses, sehingga dapat dilanjutkan dengan uji
BNT pada taraf $5 \%$, hasilnya seperti dapat dilihat pada Tabel 3.

Tabel 3. Data rata-rata jumlah feses berdasarkan konsistensi tiap kelompok perlakuan

\begin{tabular}{cccccc}
\hline Perlakuan & \multicolumn{4}{c}{ Konsistensi feses } \\
\cline { 2 - 6 } & \multicolumn{3}{c}{ I } & II & III \\
\hline A & 8 & a & $8,2 \mathrm{a}$ & 10,4 & $\mathrm{a}$ \\
$\mathrm{B}$ & 4 & $\mathrm{ab}$ & $6,4 \mathrm{ab}$ & 8,2 & $\mathrm{~b}$ \\
$\mathrm{C}$ & 4,2 & $\mathrm{bc}$ & $3,2 \mathrm{~b}$ & 6,4 & $\mathrm{ab}$ \\
$\mathrm{D}$ & 4,4 & $\mathrm{~b}$ & $2,2 \mathrm{c}$ & 6,4 & $\mathrm{bc}$ \\
$\mathrm{E}$ & $10,2 \mathrm{~b}$ & $2,2 \mathrm{c}$ & 0 & $\mathrm{c}$ \\
\hline Keterangan: & Angka & yang diikuti & huruf \\
superskrip berbeda menunjukkan & beda \\
nyata berdasarkan uji BNT 5\%. & &
\end{tabular}

Berdasarkan Tabel 3, jumlah feses berdasarkan konsistensi tiap kelompok pada mencit jantan Setelah dilakukan Analisis of Variance (ANOVA) menunjukkan jumlah feses dengan konsistensi I berbeda pada tiap kelompok. Jumlah feses dengan Konsistensi I perlakuan kontrol aquades(A) berbeda nyata dengan perlakuan dosis $135 \mathrm{mg} / 40 \mathrm{gr}$ $\mathrm{BB}(\mathrm{C})$ dan perlakuan dosis obat Imodium dosis $0,4 \mathrm{mg} 0 \mathrm{grBB}(\mathrm{E})$, namun perlakuan kontrol aquades $(A)$ tidak berbeda nyata dengan perlakuan $4,5 \mathrm{mg} / 40 \mathrm{gr} B \mathrm{BB}$ dan perlakuan $45 \mathrm{mg} / 40 \mathrm{gr}$ BB.

Konsistensi II Setelah dilakukan Analisis of Variance (ANOVA) menunjukkan jumlah feses dengan konsistensi II berbeda pada tiap kelompok yaitu pada perlakuan kontrol aquades $(A)$ berbeda dengan kelompok perlakuan dosis 45mg/ 40gr $\mathrm{BB}(\mathrm{C})$, perlakuan dosis $135 \mathrm{mg} / 40 \mathrm{mg} \mathrm{BB}(\mathrm{D})$, dan perlakuan obat Imodium dosis $0,4 \mathrm{mg} / 40 \mathrm{gr}$ $\mathrm{BB}(\mathrm{E})$, namun tidak terdapat perbedaan nyata antara perlakuan kontrol aquades $(A)$ dengan perlakuan dosis $4,5 \mathrm{mg} / 40 \mathrm{gr} \mathrm{BB}(\mathrm{B})$. 
Jumlah feses pada Konsistensi III Setelah dilakukan Analisis of Variance (ANOVA) menunjukkan jumlah feses dengan konsistensi III berbeda pada tiap kelompok yaitu pada perlakuan kontrol aquades (A) dengan perlakuan dosis $4,5 \mathrm{mg} / 40 \mathrm{gr}$ BB (B)dan perlakuan obat Imodium dosis $0,4 \mathrm{mg} / 40 \mathrm{gr}$ BB (E) dengan, namun tidak terdapat perbedaan nyata antara perlakuan kontrol aquades $(A)$ dengam perlakuan dosis 45mg/ 40gr BB (C) dan perlakuan dosis $135 \mathrm{mg} / 40 \mathrm{mg}$ BB (D) . Hal ini dapat memberikan gambaran bahwa dengan dosis 45mg/ 40gr BB (B) yang jauh lebih kecil daripada dosis $135 \mathrm{mg} / 40 \mathrm{mg}$ BB (D) sudah dapat memberikan efek antidiare. Dari uraian diatas terlihat bahwa makin besar dosis bahan uji coba yang diberikan, makin memperbaiki konsistensi feses kearah bentuk feses normal.

Loperamide $\mathrm{HCl}$. Loperamide $\mathrm{HCl}$ merupakan obat antidiare yang bekerja dengan cara bereaksi langsung pada otototot usus, menghambat peristaltis dan memperpanjang waktu transit, mempengaruhi perpindahan air dan elektrolit melalui mukosa usus, mengurangi volume fecal, menaikkan viskositas dan mencegah kehilangan air dan elektrolit (Tjay dan Rahardja, 2007). Sedangkan oleum ricini dalam menimbulkan diare dengan cara menstimulasi usus halus.

Studi fitokimia sebelumnya pada rimpang rumput teki mengandung adanya alkaloid, flavonoid, tanin, pati, glikosida dan furochromones, saponin dan seskuiterpenoid (Lawal, 2009). Beberapa senyawa turunan tannin dan flavonoid memiliki aktifitas sebagai antimotilitas, antisekretori dan antibakteri (Otshudi, et. al., 2000). Senyawa tanin mempunyai sifat adstringent yang diperlukan untuk mengatasi disentri dan diare, sifat adstringent ini mengerutkan selaput lendir usus sehingga mengurangi pengeluaran cairan diare dan disentri serta menghambat sekresi elektrolit (Tjay dan Rahardja, 2007). Beberapa penelitian juga telah melaporkan mengenai flavonoid sebagai antidiare. Mekanisme flavonoid (kuersetin) dalam menghentikan diare yang diinduksi oleh castor oil adalah dengan menghambat motilitas usus, tetapi tidak mengubah transport cairan di dalam mukosa usus sehingga mengurangi sekresi cairan dan elektrolit (Tarmudji dan Soleh, 2006; Di Carlo, et.al., 1993)

Pada penelitian ini digunakan mencit jantan karena dilihat dari fungsi biologisnya tidak mengalami siklus estrus seperti mencit betina. Selain itu hormon estrogen dan progesteron yang dimiliki mencit betina dapat mempengaruhi kerja sistem imun. Mencit betina mempunyai stadium ovulasi yang berbeda-beda antara individu satu dengan yang lain, sehingga kadar estrogen dan progesteron juga tidak sama untuk setiap mencit betina Perbedaan ini yang dapat mempengaruhi kerja obat (Hanny, 2012).

\section{KESIMPULAN}

Hasil penelitian dapat disimpulkan bahwa ekstrak rimpang rumput teki (Cyperus rotundus L.) dengan dosis $135 \mathrm{mg} / 40 \mathrm{grBB}$ dapat menunjukan adanya khasiat antidiare, tetapi efeknya lebih kecil dibandingkan dengan obat Imodium (Loperamide). 
Efek antidiare pada bahan percobaan dapat memperpanjang waktu terjadinya diare, frekuensi diare dan dapat memperbaiki konsistensi feses. Namun efek antidiare masih lebih kecil dibandingkan dengan obat Imodium (Loperamide).

\section{DAFTAR PUSTAKA}

Arif, M. 1995. IImu Meracik Obat, Teori Dan Praktek. Cet 5. Yogyakarta Gadjah Mada University Press. Hal 107.

Duryatmo, S., 2003, Aneka Ramuan Berkhasiat Dari TemuTemuan, Cetakan 1, Jakarta: Puspa Swara

Hanny, F. Y. 2012. Efek Ekstrak Umbi Rumput Teki (Cyperus rotundus L.) Sebagai Antipiretik Pada Tikus Wistar Jantan Yang Diinduksi Vaksin DPT-Hb. Skripsi S1. Fakultas Kedokteran Gigi Universitas Jember. Jawa Timur.

Harrison, 1999, Prinsip-prinsip IImu Penyakit Dalam, Edisi 13, Volume 1, EGC, Jakarta.

Lawal, O.A. dan O, Adebola. 2009. Chemical Composition of The Essential Oils of Cyperus Rotundus L. From South Africa. Journal Molecules 2009,14. Hal 29092917.

Otshudi, L.A., Vercruysse, A., and Foriers A., 2000, Contribution to the Ethnobotanical, Phytochemical and Pharmacological Studies of Traditionally Used Medicinal Plant in the Treatment of Dysentery and Diarrhoea in Lomela Area, Democratic Republik of Congo (DRC), Journal of Ethnopharmacol, $71(3): 411-423$
Tarmudji \& Soleh, M., 2006, Tabloid Sinar Tari, Bogor: Balitvet Bogor

Tjay, TH \& Rahardja, K., 2007, Obat-obat Penting: Khasiat Penggunaan dan Efek Sampingnya. Edisi IV, Gramedia, Jakarta 